\title{
District flood vulnerability index: urban decision-making tool
}

\author{
H. Nasiri' ${ }^{1}$ - M. J. M. Yusof ${ }^{1}$-T. A. M. Ali ${ }^{2}$ M. K. B. Hussein ${ }^{3}$
}

Received: 1 March 2017 / Revised: 10 November 2017 / Accepted: 14 May 2018 / Published online: 23 July 2018

(c) The Author(s) 2018

\begin{abstract}
Flood vulnerability assessment as an essential part of the urban flood management is done by various methods by several researchers. In fact, the improvement in assessment methods is related to the necessity for enhanced decision-making procedures; for instance, economic or infrastructural investments in cities can be assigned in the best form. To achieve this aim, introducing indices for evaluating vulnerability and identifying more vulnerable zones and then doing relevant comparisons can be useful. District flood vulnerability index (DFVI) developed by the author uses 25 indicators in its calculation. Nevertheless, it is obvious that some of these indicators have no effect on the consequences. This paper presents the results of the analysis for the selection of the most significant indicators of the DFVI construction. This index is appropriate for urban district scaling (or: the urban district scale) and the various components of flood vulnerability (social, economic, environmental and physical). DFVI was made by analyzing the indicators' relevance and by studying the main indicators needed to depict reality of the urban district floods in an effective way. For this purpose, expert elicitation was done by Delphi and AHP method in two separate phases. Then, all these results were combined in order to construct DFVI equations. Finally, the index was implemented in Kuala Lumpur city's districts. This paper outlines which district of cities (in this case Kuala Lumpur) are most vulnerable to flood hazard with regard to the system's components, that is, social, physical, environmental and economic.
\end{abstract}

Keywords Vulnerability assessment $\cdot$ Flood vulnerability index $\cdot$ Fuzzy Delphi $\cdot$ AHP method $\cdot$ Urban district scale

\section{Introduction}

Flood hazards are expected to occur more severely and frequently because of the effects of climate change. As a result, many areas in the world are facing the serious threat of flood hazards. Unplanned or poorly planned urbanization, rapid conversion in land use, and fragile flood management are some of the factors contributing to adverse flood effects which would lead to escalating risks for the inhabitants (Nasiri et al. 2016). This paper argues flood vulnerability

Editorial responsibility: M. Abbaspour.

H. Nasiri

Hajarnasiri1357@gmail.com

1 Urban Planning and Design Department, Design and Architecture Faculty, Putra University of Malaysia, Serdang, Malaysia

2 Department of Civil Engineering, Engineering Faculty, Putra University of Malaysia, Serdang, Malaysia

3 Landscape Department, Design and Architecture Faculty, Putra University of Malaysia, Serdang, Malaysia assessment as the vital part of urban flood management. During the International Decade of Natural Disaster Reduction (IDNDR) from 1990 to 1999, it was recognized that the earlier concept of "flood protection" was inappropriate (UNISDR 2009). There cannot be complete protection, which is inaccessible and cannot be sustained, due to very high costs and inherent unpredictability. Flood management has been suggested as a realistic alternative, because it is more applicable and this concept is now being increasingly accepted and practiced in environmental studies. Flood risk management encompasses a wide group of subjects and tasks extending from the forecasting the risk, their social implications to methods and tools to minimize risks and economic costs and loss of human lives to adequate and acceptable levels. Avoiding, decreasing or shifting the effects of flood for mitigation and adaptation is the primary objective of flood risk management (UNISDR 2009). Two approaches exist in facing flood: structural (flood protection) and nonstructural measures. Structural measures involve expanding the infrastructure like levees, dams or river dikes that alter the river flow (Faisal et al. 1999). The basic principle 
requires storage, diversion and confinement of floods. Nonstructural measures involve numerous mitigation actions but do not include altering the river flow. They cover training, flood insurance, assessment methods, emergency services, land-use planning, construction codes, warning and forecasting, etc. (Ballesteros-Cánovas et al. 2013). The goal is to reduce loss of life and property, but it is inevitable, even structural measures could have useful consequences for a specific period; they also lead to potential threats as well because they rebuild natural processes but do not follow natural rules (Gao et al. 2007).

In flood risk management, flood risk is generally based on three factors: hazard, exposure and vulnerability (Roberts et al. 2009). Hazard is the extreme natural event including its frequency; exposure refers to the people, their environment and properties affected by flood; and vulnerability refers to the susceptibility of people and properties and the coping capacity to deal with flood impact (Kron 2009). In this regard, to decrease the impact of flood through flood management, the evaluation of flood risk constituents is unavoidable. Hence, evaluation of vulnerability is an important element of flood management and decreasing vulnerability is becoming more significant aspect of this kind of management, with population increasing in urban areas (Ahmad and Simonovic 2013). To achieve this aim, vulnerability assessment methods development is very appropriate (De Moel et al. 2012). There are diverse distinctions in the current methodologies for hazard vulnerability around the world. As regards to previous works with emphasizes on flood hazard, vulnerability assessment primary methods can be clustered into three groups (Huang et al. 2012).

Table 1 mentions these methods which are used by other researchers and describes the brief weaknesses and strengths of each group.

In the context of cities, urban planners have expanded urban management measures to tackling hazard impacts by simplifying the decision-making process and helping city authorities (Kang 2009). One of these measures is presenting new indexes for assessing vulnerability and recognizing more vulnerable regions.

Current paper presents attempts to decrease the scale of flood vulnerability index from large city to district scale of inner city, because different scales have dissimilar indicators which make them vulnerable to floods. This is desired for orienting future urban growth away from risk areas and promotes a resilient-district concept for which there is a need to recognize the most vulnerable areas of each city. The previous flood vulnerability indexes focus on large scale neglecting some of the factors which change the vulnerability of smaller spatial scales, such as urban districts. Accordingly, this study aims to develop flood vulnerability index with significant local factors and provides more comprehensive interpretation of these factors being suitable for district scale.

\section{Theoretical framework}

Urban systems can be vulnerable to floods because of three main aspects: exposure, susceptibility and resilience. As such, vulnerability of urban area reflects the exposure and susceptibility of the city to flooding and the resilience of that region to cope and recover from the impact of the flood. (Smit and Wandel 2006).

As mentioned, for assessing vulnerability of human systems, one of the simple methods is index construction. The index is a quantitative variable that would allow comparison of the disaster risk and its impacts between varied areas exposed to flood. (Birkmann 2007) Every index is conducted first by identifying the most suitable type of data to counting vulnerability and second recognizing available data at the spatial scale of study (Mclaughlin and Cooper 2010). The indexes let us to identify aims and provide strategies guidance to reduce vulnerability and to set more precise and quantitative targets for vulnerability decrease. (Balica 2007).

The flood vulnerability index is a method to assess flood vulnerability based on: river basin, sub-catchment, and urban area scales by categorizing different components that affect the susceptibility of the people who live in flood prone areas. The previous indexes identified four main social, economic, environmental and physical components which are specified by some indicators in (Balica 2007) research and Meteorological, Hydrogeological, Socioeconomic and Countermeasure Components in (Connor and Hiroki 2005) study.

Connor and Hiroki (2005) calculated this index for river basin system and stated that there are a lot of factors except precipitation and runoff, which influence a basin's flood vulnerability such as preparedness and resilience capacity. They suggested four key components in a river basin, which affect flood vulnerability; Meteorological Component (MC), Hydrogeological Component (HC), Socioeconomic Component (SC), and Countermeasure Component (CC). Balica (2007) extended this definition to sub-catchment and urban systems. She recognized another four components for these two scales: economic, environmental, social and physical components, which can be assessed by various indicators. Interaction between these components and the mentioned factors of the system (exposure, resilience and susceptibility) is the basis of flood vulnerability index methodology (Fig. 1). The social component ensures the vulnerability of an area to a flood in terms of social development. Physical components include physical condition, both natural and artificial, which affects flood vulnerability of a specific area. Environmental component consists of indicators which mention the environmental damages caused by flood hazard or 
Table 1 Comparison vulnerability assessment methods. Source: Huang et al. (2012), Balica et al. (2013), Nasiri and Shahmohammadi-kalalagh (2013)

\begin{tabular}{|c|c|c|c|}
\hline Method & Vulnerability index method & Disaster loss estimation & Modeling \\
\hline $\begin{array}{l}\text { Character- } \\
\text { istics }\end{array}$ & $\begin{array}{l}\text { Extensively used in flood vulnerability } \\
\text { researches } \\
\text { Covers all aspects of human system } \\
\text { like social or economic aspect which } \\
\text { neglected in other methods } \\
\text { Be influenced by complicated indices and } \\
\text { weighting of their subjective } \\
\text { Can use other relative indicators in data } \\
\text { shortage for special indicator } \\
\text { Very simple for using by decision makers } \\
\text { for comparing regions }\end{array}$ & $\begin{array}{l}\text { Because of imprecise and randomly } \\
\text { documented data, outcome should be } \\
\text { treated caution } \\
\text { Is based on actual damage survey } \\
\text { Takes a lot of time and resource } \\
\text { Not applicable for other regions(Specific } \\
\text { site) }\end{array}$ & $\begin{array}{l}\text { Unintelligible for public } \\
\text { Low validity in data shortage condition } \\
\text { Using these methods need some specific } \\
\text { expertise which are sometime not very } \\
\text { simple to learn }\end{array}$ \\
\hline
\end{tabular}

artificial interventions, which can raise the vulnerability of a particular area and finally economic components include economic issues such as income, economic activities, industries, agriculture and power production, which are affected by flooding (Balica 2007).

As regards to this theoretical framework, for introducing flood vulnerability index for Kuala Lumpur context, it is essential to identify the flood vulnerability components (physical, economic, environmental and social) and their indicators for Kuala Lumpur city and determine the most significant indicators which are appropriate for the district scale through expert opinions and regulate weights of selected indicators to define the index then at the end construct the district flood vulnerability index (DFVI) for Kuala Lumpur districts.

\section{Malaysia case study}

Malaysian cities are fortunate as they do not face hazards like earthquakes, but intensive floods happen regularly. Flash floods and monsoon floods are two kinds of floods that occur rather frequently in Malaysia. Table 2 displays

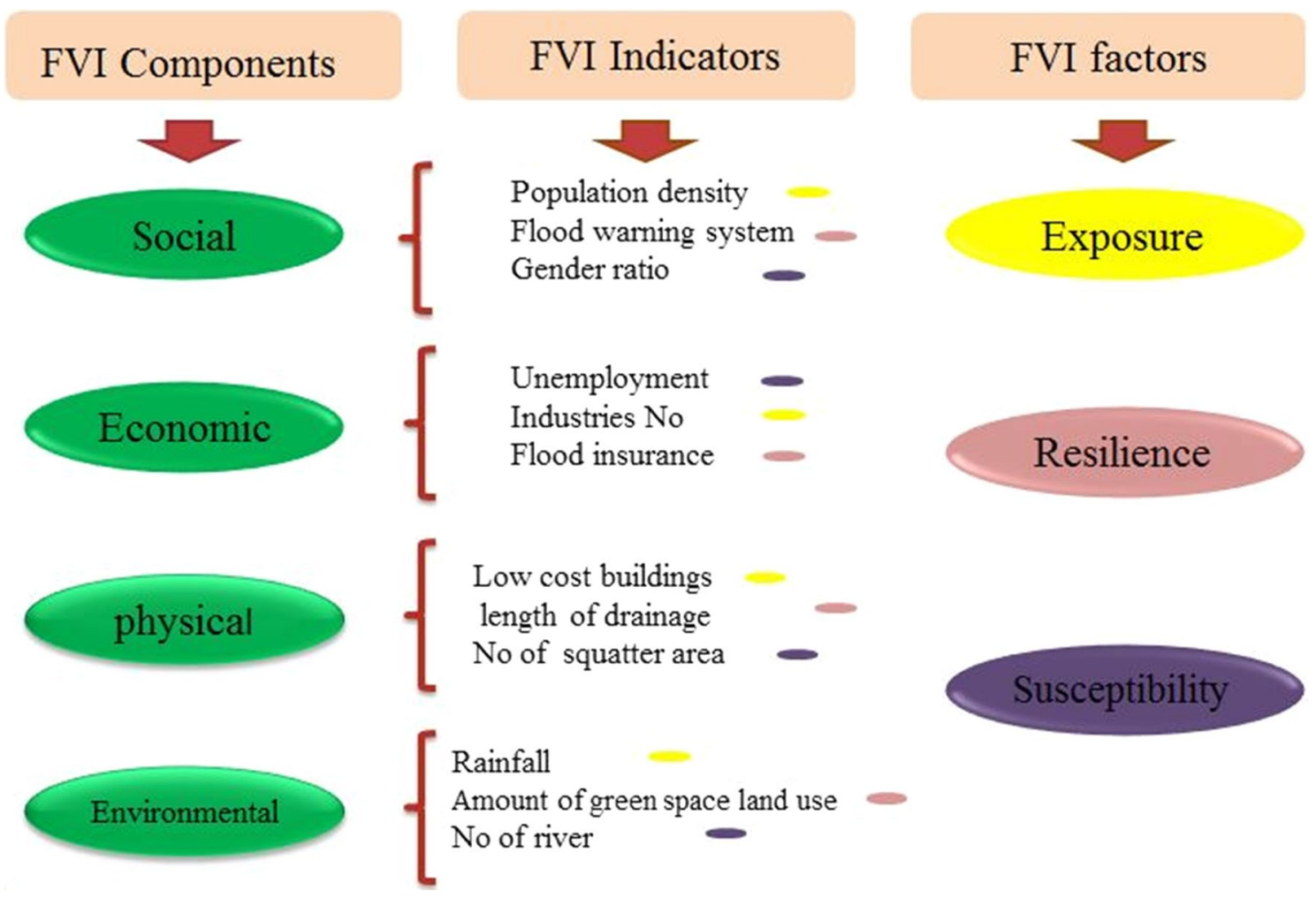

Fig. 1 Flood vulnerability index structure. Source: Author 
Table 2 Most important floods in Malaysia

\begin{tabular}{llll}
\hline Date & $\begin{array}{l}\text { No. of people affected } \\
\text { in total }\end{array}$ & $\begin{array}{l}\text { Cost of damage } \\
(000 . U S \$)\end{array}$ & Location \\
\hline Jan 1967 & 140,000 & 25,600 & Kelantan \\
26.12 .1970 & 243,000 & 37,000 & Kuala Lumpur \\
28.11 .1986 & 250,000 & 11,500 & Kelantan \\
2003 & - & Unknown & Kedah, Kuala Lumpur \\
$2006-2007$ & 176,533 & 990,000 & Johor, Malacca, Pahang, Negeri Sembilan, \\
& & 21,000 & Shah Alam, Kuala Lumpur \\
28.12.2008 & 6000 & 8000 & Johor, Terengganu, \\
3.11.2010 & 50,000 & Unknown & Kajang, Kuala Lumpur (Jalan Tun Razak) \\
28.1.2011 & 20,000 & Unknown & Pahang, Terengganu, Johor \\
5.12.2013 & 37,000 & 9.42 billion & Johor, Kedah, Kelantan, Pahang, Perak, \\
15 Dec 2014 & More than 200,000 & & Perlis, Sabah, Sarawak, Selangor and \\
3 January 2015 & & & Terengganu \\
& & &
\end{tabular}

ADRC (2011), Guha-Sapir et al. (2014), Chan (2015), Abustan and Wahid (2008), Nasir (2015)
Fig. 2 DFVI construction flowchart. Source: Author

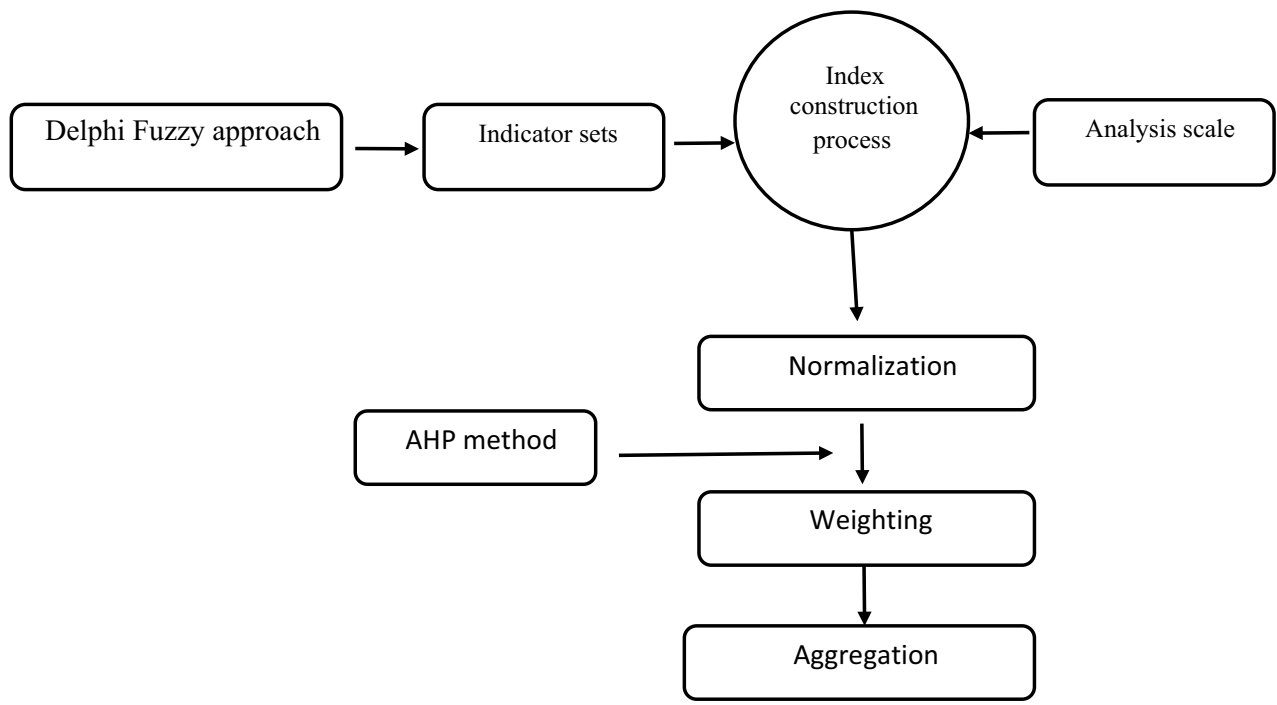

the most serious flood events in Malaysia between 1950 and 2015 which are arranged by number of people affected and extent of economic losses. But few studies have been done on introducing indexes on this area.

In fact, DFVI approach is one of the initial index methods for flood vulnerability assessment in urban district scale and the first structured effort to assess flood vulnerability with indexes in Malaysia. This will be more imperative when vulnerability assessment is a requirement of the European flood directive 2007/60/EC (Parliament and Committee 2007) for reducing natural hazard risk. In such a way, Kyoto 2005 manifesto (governments across the world obligate to proceed for reduce disaster risk and approved a guideline to decrease vulnerabilities to natural hazards, called the Hyogo Framework for Action (HFA)) has mentioned indicatorsbased approaches to different scales for observing disaster risk and vulnerability, and rise the capability of countries to manage risks (United Nations 2005; Balica et al. 2013). As a result, the indicators through the index can be a director to understanding the current and future state of an area in facing with natural hazards.

\section{Materials and methods}

For developing the new index, the model construction flowchart (Fig. 2) was beneficially used as an initial step. In the first step, a set of indicators from different sources was gathered. For screening more appropriate indicators for urban district scale, which will make a district vulnerable to floods, expert elicitation was done through Delphi Fuzzy method. With regard 
Table 3 Defuzzification results of aggregated experts' values for all DFVI components

\begin{tabular}{|c|c|c|c|c|}
\hline Components & Indicators & Opinions' mean & Crisp value & Result \\
\hline \multirow[t]{6}{*}{ Social } & Population density & $(0.57,0.82,0.93)$ & 0.77 & Approved \\
\hline & Elderly population & $(0.215,0.42,0.665)$ & 0.433 & Rejected \\
\hline & Racial composition of district (Malay, Chinese, Indian) & $(0.11,0.23,0.47)$ & 0.27 & Rejected \\
\hline & Gender Ratio(male/female) & $(0.125,0.29,0.525)$ & 0.31 & Rejected \\
\hline & Flood hazard map existence in district & $(0.49,0.72,0.87)$ & 0.69 & Approved \\
\hline & Warning system existence & $(0.44,0.675,0.83)$ & 0.64 & Rejected \\
\hline \multirow[t]{6}{*}{ Physical } & Proportion of low-cost buildings & $0.535,0.78,0.91$ & 0.74 & Approved \\
\hline & Length of drainage system & $0.665,0.915,0.98$ & 0.85 & Approved \\
\hline & No. of cultural heritage & $0.285,0.51,0.725$ & 0.50 & Rejected \\
\hline & No. of Hospital/Clinic & $0.395,0.64,0.805$ & 0.613 & Rejected \\
\hline & No. of public transportation stations & $0.195,0.355,0.575$ & 0.375 & Rejected \\
\hline & No. of Squatter area & $0.34,0.585,0.785$ & 0.57 & Rejected \\
\hline \multirow[t]{7}{*}{ Environmental } & Amount of rainfall & $0.69,0.94,0.985$ & 0.87 & Approved \\
\hline & No. of River & $0.65,0.895,0.955$ & 0.83 & Approved \\
\hline & Amount of open land use in each district & $0.53,0.78,0.92$ & 0.74 & Approved \\
\hline & Temperature fluctuations & $0.36,0.585,0.775$ & 0.571 & Rejected \\
\hline & Runoff amount from rainfall regards to different land uses & $0.51,0.755,0.915$ & 0.72 & Approved \\
\hline & Average slope of district & $0.41,0.65,0.825$ & 0.62 & Rejected \\
\hline & No. of environmental protection zones & $0.195,0.365,0.595$ & 0.385 & Rejected \\
\hline \multirow[t]{5}{*}{ Economic } & No of industries unit & $0.525,0.755,0.9$ & 0.72 & Accepted \\
\hline & Unemployment rate & $0.175,0.29,0.52$ & 0.32 & Rejected \\
\hline & Be existent of flood insurance & $0.315,0.55,0.755$ & 0.54 & Rejected \\
\hline & Be existent of crisis management office in district & $0.37,0.585,0.76$ & 0.571 & Rejected \\
\hline & No. of commercial units & $0.54,0.77,0.92$ & 0.74 & Accepted \\
\hline
\end{tabular}

Table 4 Final indicators for DFVI

\begin{tabular}{|c|c|c|c|c|c|}
\hline No. & Abb. & Name & Units & $\mathrm{FV}$ factor & Definition \\
\hline 1 & $P_{d}$ & Population density & $\frac{\text { People }}{1 v^{2}}$ & Exposure & There is an important exposure to flood if population is concentrated \\
\hline 2 & $F_{m}$ & Flood map existence & - & Resilience & If there is no $F_{m}$, then the value is 1 , if yes, the value is 10 (Balica et al. 2013) \\
\hline 3 & $L_{c \cdot b}$ & Low-cost building & $\%$ & Exposure & $\begin{array}{l}\text { The condition of low-cost buildings: (Shuid 2004) } \\
\text { Poor quality of construction and material } \\
\text { Space standards determined } 60-65 \mathrm{~m}^{2} \\
\text { High density of people ( } 150 \text { people per hectare } \\
\text { Shortage of car parking space } \\
\text { Affordability for House (RM):below RM85,000 }\end{array}$ \\
\hline 4 & $D_{l}$ & Drainage length & $\mathrm{km}$ & Resilience & More drainage, less vulnerability \\
\hline 5 & $R_{a}$ & Rainfall amount & $\mathrm{m} /$ year & Exposure & Higher rainfall, higher vulnerability \\
\hline 6 & $\mathrm{R}$ & River No. & Number & Susceptibility & More river, higher vulnerability \\
\hline 7 & & Open space land use & Hec. & Resilience & Open space increase leads to low vulnerability \\
\hline 8 & $S_{t}$ & Runoff amount & $\frac{\mathrm{m}^{3}}{\mathrm{~s}}$ & Exposure & $\begin{array}{l}\text { Runoff rate used for this item which refers to Runoff coefficient data and the } \\
\text { area of each type of land use in each district (Dingman 2002; Wong 1970) }\end{array}$ \\
\hline 9 & $I$ & Industries & $\mathrm{Sq}^{2}$ & Susceptibility & The higher number, higher vulnerability \\
\hline 10 & $C$ & Commercial units & $\mathrm{Hec}$ & Susceptibility & The higher amount of commercial land use, higher vulnerability \\
\hline
\end{tabular}




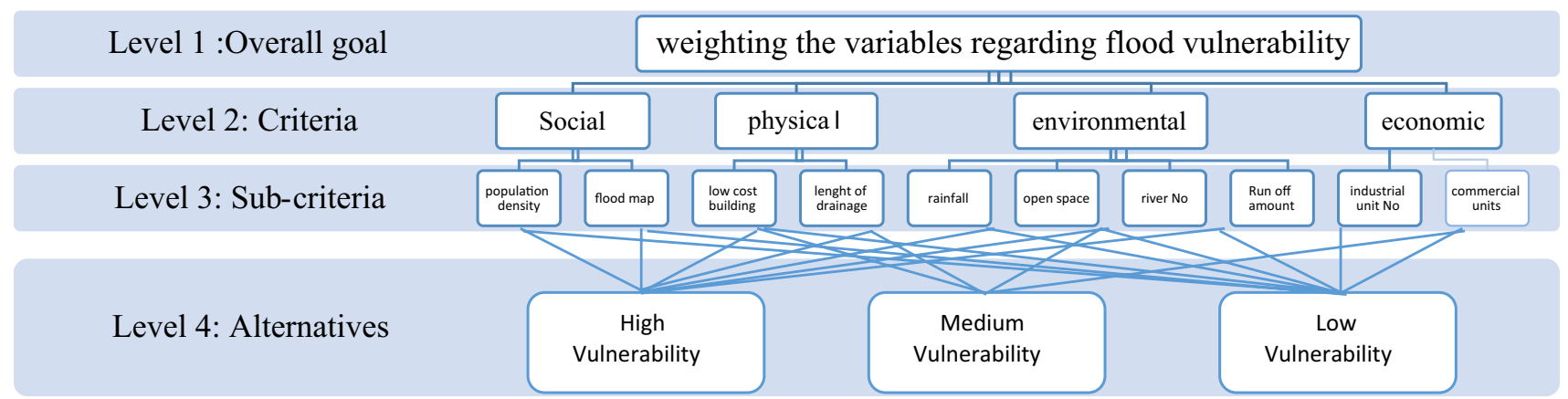

Fig. 3 A hierarchy for flood vulnerability indicators weight decision. Source: Author

to respondents' time limitations and with respect to accomplishing one round Delphi survey, which is assumed sufficient for screening the variables, researcher decided to choose this method for extraction of experts' opinion.

Five point Likert scale questionnaires' results which filled out by Kuala Lumpur urban planning and urban flood experts were accumulated in fuzzy pattern. Considerable discussion and consultation has been devoted to the identification of the variables used in the calculation of the DFVI. The primary indicator set which are more suitable for district scale is mentioned in results section.

\section{Results and discussion}

Recent section is divided into some steps: first is the screening the different indicators of an urban district which will make it vulnerable to floods through Delphi Fuzzy method. Second part presents the indicator weighing achieved by AHP methodology. For running the AHP method in the DFVI construction process, expert choice software is employed. At that moment, index construction was completed. It is followed by implementation of the constructed index in case studies and comparison of the indices in six strategic zones of Kuala Lumpur, aggregating the indicators in terms of vulnerability index. The acceptance and rejection of variables are also matters of threshold value that are determined by the researcher. The threshold is determined as 0.7 for this research. Those variables which show a real score higher than the threshold value after defuzzification were taken, and the rest discarded.

The final indicators for DFVI which gained from Delphi survey are presented in Tables 3, 4.

The next step in index construction is determining the weight of each indicator for using in index equation. By using the analytic hierarchy process (AHP) pairwise comparison process, weights or priorities are derived from a set of judgments. Once the model is built, the next phase is to evaluate the elements by making pairwise comparison hierarchy tree. This pairwise tree in this study can be divided into four parts as shown in Fig. 3:

- goal (weighting DFVI's indicators),

- criteria (social, physical, environmental and economic)

- sub-criteria (population density, flood map existence, low-cost building, length of drainage, rainfall, runoff amount, river number, open space land use, number of industrial units and commercial units)

- alternatives (high vulnerability zone, medium vulnerability zone and low vulnerability zone)

The final normalized weights for selected indicators are presented in Table 5.

After weights have been assigned to each component of index between diverse ways in which variables can be combined to form an index, we follow the composite index approach, as used in the construction of the Human Development Index and social vulnerability index and most of environmental issues. Index aggregation was done with regard to two equations.

First: Additive aggregation is implemented in the index as a weighted linear combination of normalized indicators

$y=\sum_{i=1}^{n} W_{i} X_{i}$

Second: Flood vulnerability equation (Connor and Hiroki 2005; Balica and Wright 2010) respects to exposure, susceptibility and resilience components

$F V=\frac{E \times S}{R}$

where $E$ shows all the indicators in exposure factor, $S$ contains all the indicators in susceptibility factor and $R$ covers the resilience indicators.

With merging these two equations, Eq. (3) is achieved

DFVID $=\frac{\sum_{E=1}^{n} X_{E} \cdot W_{E} \times \sum_{s=1}^{n} X_{S} \cdot W_{S}}{\sum_{R=1}^{n} X_{R} \cdot W_{R}}$ 
where, $X_{E}$ : District vulnerability indicators in exposure factor, $W_{E}$ : Weight of Exposure factor indicators, $X_{S}$ : District vulnerability indicators in susceptibility factor, $W_{S}$ : Weight of susceptibility factor indicators, $X_{R}$ : District vulnerability indicators in resilience factor, $W_{R}$ : Weight of resilience factor indicators.

According to assigned weights to each of the district indicators which are attained in previous part (Table 5), subsequently final indexes are achieved

District social flood vulnerability

DFVIsocial $=\left[\frac{0.165 P_{D}}{0.143 \text { flood }_{\text {map }}}\right]$

District physical flood vulnerability

$\operatorname{DFVI}_{\text {physical }}=\left[\frac{0.203 L_{C . B}}{1 * D_{L}}\right]$

District environmental flood vulnerability

$\operatorname{DFVI}_{\text {Environmental }}=\left[\frac{0.782 \text { Rainfall }+0.774 \text { Runoff* } * .219 R}{0.154 \mathrm{O}_{\mathrm{LU}}}\right]$

District economic flood vulnerability

$\mathrm{DFVI}_{\text {Economic }}=[0.076 \mathrm{I}+0.090 C]$

Overall $_{\mathrm{DFVI}}=\mathrm{DFVI}_{\text {Social }}+\mathrm{DFVI}_{\text {physical }}+\mathrm{DFVI}_{\text {Environmental }}$ + DFVI $_{\text {Economic }}$

Pilot implementation of DFVI at Kula Lumpur districts

The implementation of flood vulnerability index is done within the context of a particular place. For this research, the test bed for the analysis is the Kuala Lumpur city due to the devastation this area suffered from flooding. Kuala Lumpur as the federal capital is most inhabited city in Malaysia. Population data reveal nearly 1.6 million people resided within the $243 \mathrm{~km}^{2}$ area. Kuala Lumpur is distinct within the boundaries of the Federal Territory of Kuala Lumpur. It is a district within the state of Selangor, on the central west coast of Peninsular Malaysia (DBKL 2004). Kuala Lumpur megacity has been divided into six strategic zones for city plan 2020 whose boundaries support with major roads, rails and river corridors. These strategic zones can be used as this research required scale because they are the most suitable small scale inner the Kuala Lumpur with more available data for running the vulnerability index model. This division includes the following areas (Fig. 4).

Alongside the DFVI values for each district, normalized results are presented for further comparison and also 


\section{Major Rivers}

$1 \mathrm{Sg}$. Klang

2 Sg. Batu

$3 \mathrm{Sg}$. Gombak

\section{Main Rivers}

$4 \mathrm{Sg}$. Kerayong

$5 \mathrm{Sg}$. Kuyuh

6 Sg. Bohol

7 Sg. Penchala

8 Sg. Jinjang

9 Sg. Keroh

10 Sg. Kemunsing

$11 \mathrm{Sg}$. Belongkong

Minor Rivers

$12 \mathrm{Sg}$. Bunus

$13 \mathrm{Sg}$. Toba

14 Sg. Pantai

15 Sg. Kayu Ara

16 Sg. Air Busuk

$17 \mathrm{Sg}$. Beberas

$18 \mathrm{Sg}$. Bras-Bras

$19 \mathrm{Sg}$. Utut

$20 \mathrm{Sg}$. BatangTolak

$21 \mathrm{Sg}$. Anak Air Batu

$22 \mathrm{Sg}$. Merali

23 Sg. Petaling

Flooded area

1 Jalan Pudu/Cheras

2 Jalan Sg. Besi

3 TUDM

4 Jalan Klang Lama

5 Taman Kuchai Jaya,

Jalan Kuchai Lama

$6 \mathrm{Kg}$. Sg. Bohol

7 Kg.Boyan

8 Jalan Tun Razak

9 Kawasan setinggan(Sg. Bunus $\mathrm{C}$ )

10 Sg.Baru Flat

$11 \mathrm{Kg}$. Limau

$12 \mathrm{Kg}$. Periuk

$13 \mathrm{Kg}$. Bandar Dalam

$14 \mathrm{Kg}$. Chubadak

$15 \mathrm{Kg}$. Bentang

$16 \mathrm{Kg}$. Sg. Udang

$17 \mathrm{Kg}$. Jalan Tioman

$18 \mathrm{Kg}$. Jalan Langkawi

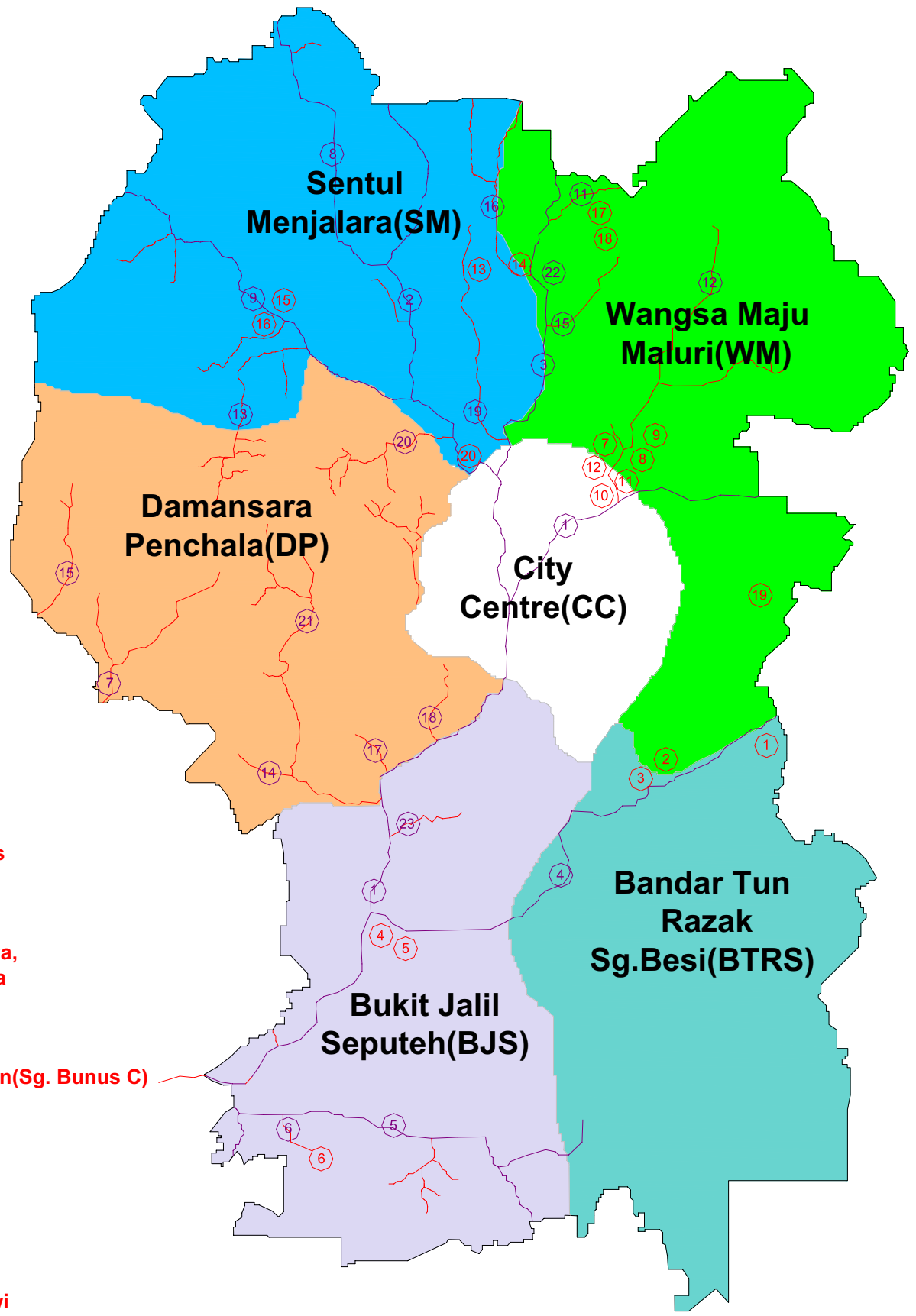

$19 \mathrm{Kg}$. Jalan Kg. Pandan

$20 \mathrm{Kg}$. Jalan Ipoh

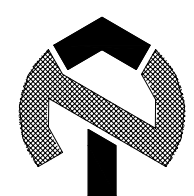

Fig. 4 Strategic zones of Kuala Lumpur with rivers and flooded area. Source: DBKL 2004 
Table 6 Final district flood vulnerability index in Kuala Lumpur context

\begin{tabular}{lllllll}
\hline District & Wangsa Maju & Sentul & Damansara & City Center & Bukit Jalil & $\begin{array}{l}\text { Bandar } \\
\text { Tun- } \\
\text { Razak }\end{array}$ \\
\hline Overall DFVI & 4.79 & 3.94 & 3.682 & 4.76 & 2.73 & 2.43 \\
Normalized DFVI & 1 & 0.822 & 0.768 & 0.99 & 0.56 & 0.50 \\
\hline
\end{tabular}

serve the purpose of easier interpretation (Table 6). Figure 5 shows these values in graphical form.

\section{Conclusion}

The application of the district flood vulnerability index could offer a unique attitude to the assessment of vulnerability to floods in a more precise and local manner. Media and policy-makers consider rising attention at composite indexes as an attractive tool to draw the community's caution and help by concentrating on policy debates. In this regard, DFVI construction method has been presented. The district-based DFVI offered comparative information on many characteristics of vulnerability and flood risk. Nevertheless, this method also increased challenging questions about the selection and aggregation of the indicators. Some of the chosen and combined indicators were found to be redundant to a certain extent. Moreover, some indicators were found to be very context-specific and thus need to be selected with precaution when applying them for other societies and scales. For example, indicators such as "rainfall amount" or "river number" could be different in district of tropical mega cities (e.g., Kuala Lumpur), but in other geographical regions no meaningful difference between city districts' rainfall amount was noticed. For instance, the rainfall amount does not provide meaningful insights when comparing districts of the same city in dry semiarid climate. Consequently, alternative indicators will be needed. In

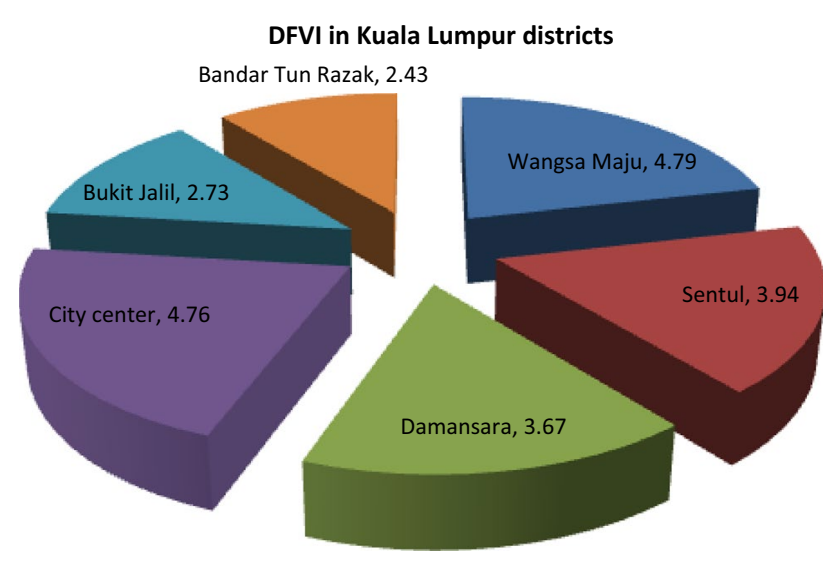

Fig. 5 Flood vulnerability index for each district of Kuala Lumpur other words, modifications are required in the index method in order to ensure that the approach evaluates the context, such as the differences between districts in different climatic regions. In conclusion, DFVI approach was found a suitable scheme which enables an interesting composing of indicators for physical, environmental, social and also economic vulnerability on the local level.

Acknowledgements I thank my supervisor for very helpful comments and insights. Many thanks to Kuala Lumpur Municipality, Drainage and Irrigation Department of Malaysia (DID) for the help in providing data.

Open Access This article is distributed under the terms of the Creative Commons Attribution 4.0 International License (http://creativeco mmons.org/licenses/by/4.0/), which permits unrestricted use, distribution, and reproduction in any medium, provided you give appropriate credit to the original author(s) and the source, provide a link to the Creative Commons license, and indicate if changes were made.

\section{References}

Abustan I, Wahid NA (2008) The vulnerability of Malaysia in facing flood experiences

ADRC (2011) Country report of MALAYSIA 2011

Ahmad SS, Simonovic SP (2013) Spatial and temporal analysis of urban flood risk assessment. Urban Water J 10(1):26-49

Balica SF (2007) Development and application of flood vulnerability indices for various spatial scales. Water Science and Engineering, Delft

Balica S, Wright NG (2010) Reducing the complexity of the flood vulnerability index. Environ Hazards 9(4):321-339

Balica SF, Popescu I, Beevers L, Wright NG (2013) Parametric and physically based modelling techniques for flood risk and vulnerability assessment: a comparison. Environ Model Softw 41:84-92

Ballesteros-Cánovas JA, Sanchez-Silva M, Bodoque JM, Díez-Herrero A (2013) An integrated approach to flood risk management: a case study of Navaluenga (Central Spain). Water Resour Manag 27(8):3051-3069

Birkmann J (2007) Risk and vulnerability indicators at different scales: applicability, usefulness and policy implications. Environ Hazards 7(1):20-31

Chan NW (2015) Impacts of disasters and disaster risk management in malaysia: the case of floods. In: Resilience and recovery in Asian disasters. Springer, Japan, 239-265

Connor RF, Hiroki K (2005) Development of a method for assessing flood vulnerability. Water Sci Technol 51(5):61-67

DBKL (2004) kl structure plan 2020

Dingman SL (2002) Water in soils: infiltration and redistribution. Phys Hydrol

Faisal IM, Kabir MR, Nishat A (1999) Non-structural flood mitigation measures for Dhaka City. Urban Water 1(2):145-153 
Gao J, Nickum JE, Pan Y (2007) An assessment of flood hazard vulnerability in the Dongting Lake Region of China. Lakes Reserv: Res Manag 12(1):27-34

Guha-Sapir D, Below R, Hoyois P (2014) EM-DAT: international disaster database. (CRED), Centre for Research on the Epidemiology of Disasters

Huang D, Zhang R, Huo Z, Mao F, Youhao E, Zheng W (2012) An assessment of multidimensional flood vulnerability at the provincial scale in China based on the DEA method. Nat Hazards 64(2):1575-1586

Kang JE (2009) Mitigating flood loss through local comprehensive planning in Florida. Texas A\&M University, Austin

Kron W (2009) Flood insurance: from clients to global financial markets. J Flood Risk Manag 2(1):68-75

McLaughlin S, Cooper JAG (2010) A multi-scale coastal vulnerability index: a tool for coastal managers? Environ Hazards 9(3):233-248

Moel HD, Asselman NEM, Aerts JCJH (2012) Uncertainty and sensitivity analysis of coastal flood damage estimates in the west of the Netherlands

Nasir SRM (2015) Perspective of stakeholders on Flash Flood in Kuala Lumpur. In: ISFRAM 2014. Springer, Singapore, pp 51-63

Nasiri H, Shahmohammadi-Kalalagh S (2013) Flood vulnerability index as a knowledge base for flood risk assessment in urban area. J Novel Appl Sci 2(8):269-272
Nasiri H, Yusof MJM, Ali TAM (2016) An overview to flood vulnerability assessment methods. Sustain Water Resour Manag 2(3):331-336

Parliament E, Committee S (2007) Directive 2007/60/EC of the European parliament and of the council. Off J Eur Union 2455:27-34

Roberts NJ, Nadim F, Kalsnes B (2009) Quantification of vulnerability to natural hazards. Georisk 3(3):164-173

Shuid S (2004) Low medium cost housing in Malaysia: issues and challenges. In: APNHR conference

Smit B, Wandel J (2006) Adaptation, adaptive capacity and vulnerability. Glob Environ Change 16(3):282-292

UNISDR M (2009) UNISDR terminology for disaster risk redution. United Nations International Strategy for Disaster Reduction (UNISDR) Geneva, Switzerland

United Nations (2005) ISDR. Hyogo framework for action 2005-2015: building the resilience of nations and communities to disasters. In: Extract from the final report of the World Conference on Disaster Reduction (A/CONF. 206/6) (vol 380)

Wong IFT (1970) Reconnaissance soil survey of Selangor. Bull Minist Agric Lds, Malaysia, 122 